\title{
Studying Submarine Groundwater Discharge at the Cape Ayia: A Multi-Tracer Approach
}

\author{
I. I. Dovhyi ${ }^{1,}{ }^{凶}$, N. A. Bezhin ${ }^{1,2}$, D. A. Kremenchutskii ${ }^{1}$, \\ O. N. Kozlovskaya ${ }^{1}$, A. I. Chepyzhenko ${ }^{1}$, A. V. Verterich $^{3}$, \\ Ya. Yu. Tovarchii ${ }^{2}$, Yu. G. Shibetskaya ${ }^{1,2}$, D. Yu. Chaikin ${ }^{3}$ \\ ${ }^{1}$ Marine Hydrophysical Institute of RAS, Sevastopol, Russian Federation \\ ${ }^{2}$ Sevastopol State University, Sevastopol, Russian Federation \\ ${ }^{3}$ D. Mendeleev University of Chemical Technology of Russia, Moscow, Russian Federation \\ 凶dovhyi.illarion@yandex.ru
}

Purpose. The study of submarine groundwater discharge is one of the most pressing issues of modern hydrogeology and oceanography. The purpose of the paper is to provide a comprehensive study of the submarine groundwater discharge at Cape Ayia using the hydrological, hydrochemical and radiochemical methods, and to determine the flux of submarine groundwater including the nutrients. Methods and Results. The research werecarried out during the coastal expeditions nearby Cape Ayia on March 24, 2019, and on April 22-24, 2019 during the $106^{\text {th }}$ RV "Professor Vodyanitsky" cruise (April 18 - May 13, 2019). The isotopes ${ }^{226} \mathrm{Ra},{ }^{228} \mathrm{Ra}$ were extracted using the proprietary $\mathrm{MnO}_{2}$-based fibers. After concentration, the sorbent was squeezed to remove excess water, dried and ashed. Then the ash was placed in the Petri dishes and poured with epoxy resin. Activity of the radionuclides was measured on a low-background semiconductor $\gamma$-spectrometer with a detector of high-purity germanium (GC3020) 3 weeks after the resin casting. The activity of ${ }^{226} \mathrm{Ra}$ was determined by the daughter radionuclide ${ }^{214} \mathrm{~Pb}$ with the energy $351.9 \mathrm{keV}$ ( $\mathrm{q} \gamma=37.2 \%$ ), and that of ${ }^{228} \mathrm{Ra}-$ by the daughter ${ }^{228} \mathrm{Ac}\left(T_{1 / 2}=6.1 \mathrm{~h}, \mathrm{q} \gamma=27.7 \%\right)$ with the energy $911.6 \mathrm{keV}$. The basic elements of the main nutrient cycle were determined photocolorimetrically: mineral phosphorus - by molybdenum blue, silicon - by silicon-molybdenum complex. Nitrates (reduced to nitrites) and nitrites were determined by azo dye; ammonium - by indophenol blue also by the photocolorimetric method.

Conclusions. Distribution of hydrophysical, hydrochemical and radiochemical parameters in the water area connected with the known submarine groundwater discharges was studied. The distribution of the ${ }^{226} \mathrm{Ra},{ }^{228} \mathrm{Ra}$ isotopes was studied for the first time. The data on salinity, specific activity of ${ }^{226} \mathrm{Ra},{ }^{228} \mathrm{Ra}$ and the nutrients concentration permitted to determine the flows of submarine groundwaters in the Cape Ayia area, which amounted to $8220 \pm 1200 \mathrm{~m}^{3} / \mathrm{day}$. The anthropogenic contribution to pollution of the groundwater forming the submarine sources is shown.

Keywords: submarine discharge, hydrophysical, hydrochemical and radiochemical parameters, ${ }^{226} \mathrm{Ra}$, ${ }^{228} \mathrm{Ra}$

Acknowledgments: the investigation was financially supported by the RFBR and the Government of Sevastopol within the framework of project No. 18-33-50001 (competition "Tutor"), project No. 1933-60007 (competition "Perspective") and the state task of the Ministry of Education and Science of the Russian Federation (theme "Oceanological processes" No. 0827-2020-0003).

For citation: Dovhyi, I.I., Bezhin, N.A., Kremenchutskii, D.A., Kozlovskaya, O.N., Chepyzhenko, A.I., Verterich, A.V., Tovarchii, Ya.Yu., Shibetskaya, Yu.G. and Chaikin, D.Yu., 2021. Studying Submarine Groundwater Discharge at Cape Ayia: A Multi-Tracer Approach. Physical Oceanography, [ejournal] 28(1), pp. 52-66. doi:10.22449/1573-160X-2021-1-52-66

DOI: $10.22449 / 1573-160 X-2021-1-52-66$

(c) I. I. Dovhyi, N. A. Bezhin, D. A. Kremenchutskii, O. N. Kozlovskaya, A. I. Chepyzhenko, A. V. Verterich, Ya. Yu. Tovarchii, Yu. G. Shibetskaya, D. Yu. Chaikin, 2021

(C) Physical Oceanography, 2021 


\section{Introduction}

The study of submarine groundwater discharge is one of the most pressing issues of modern hydrogeology and oceanography. It is the sobjecto of a series of international projects, such as the Scientific Committee for Ocean Research (SCOR) (working group 112 "Intensity of submarine groundwater discharge and its effect on coastal oceanographic processes") [1] and the IAEA [2]. Several theses were defended based on the results of studying submarine discharge in the Mediterranean region [3, 4]. According to well-known researchers in this field [5, 6], submarine groundwater discharge is the least studied element of the water and salt balance of the seas, since the inflow cannot be measured directly.

In the Black Sea region, submarine springs are known in Romania [7]; powerful underground springs of the Arbaika Massif form an extensive submarine depression in the sea near Gagra [6, 8]. Some submarine springs are also known in Crimea [9]. Russian scientists have been studying the submarine discharge sources at Cape Ayia for about 40 years [10]. In the 1980s, the works were carried out by the Institute of Geological Sciences of the Academy of Sciences of the USSR ${ }^{1}$ [11] and the Ukrainian State Institute of Mineral Resources, Simferopol ${ }^{2}$ [12]. Since the 1990s, research was carried out at Marine Hydrophysical Institute of NAS of Ukraine [1315].

For identification of submarine sources, papers [1, 2, 16] proposed to use remote sensing technics, aerial photography, hydrological (according to salinity data) and radiochemical (radon survey) methods. To determine the flow rate of submarine sources, radio tracer methods are widely used. At the same time, different authors have proposed various approaches to the study and used different parameters of the marine environment to determine the flow rate of sources. In this paper, a comprehensive determination of hydrological, hydrochemical and radiochemical parameters was carried out to study the main, according to [15, 16], submarine source near Cape Ayia (Fig. 1).

This issue is of particular relevance due to the current situation with the water supply of the Republic of Crimea and the city of Sevastopol. After Ukraine blocked the North Crimean Canal, Crimea became a water-scarce region. Suffice it to recall the events in late 1980s - early 1990s, when at the end of the low-water decade, the water supply from the Chernorechensky reservoir (Baydarskaya Valley), one of the main sources of water supply to Sevastopol, practically stopped. The population was supplied by water for only two hours a day, all catering points, some children's institutions and other enterprises were closed [18]. A number of experts believe that 2019 is the beginning of a dry season ${ }^{3}$.

${ }^{1}$ Baysarovich, I.M., 1990. Formation and Submarine Discharge of Fractured-Karst Waters in the Coastal Zone of the Black Sea: abstract of dissertation ... cand. geol.-min. sciences. Odessa, 24 p. Available at: https://search.rsl.ru/ru/record/01000129804 [Accessed: 18 January 2021] (in Russian).

${ }^{2}$ Yurovsky, Yu.G., 1993. Features of Natural Processes in Areas of Submarine Unloading of Groundwater: abstract of dissertation ... doctor. geol.-min. sciences. Kiev, 44 p. Available at: https://search.rsl.ru/ru/record/01007033946 [Accessed: 18 January 2021] (in Russian).

${ }^{3}$ Author, n.d., 2019. Water Supply of Crimea: "The Situation Remains Unresolved and Disturbing”. Regnum, 10.01.2019. [online] Available at: https://regnum.ru/news/2550247.html [Accessed: 18 January 2021] (in Russian). 


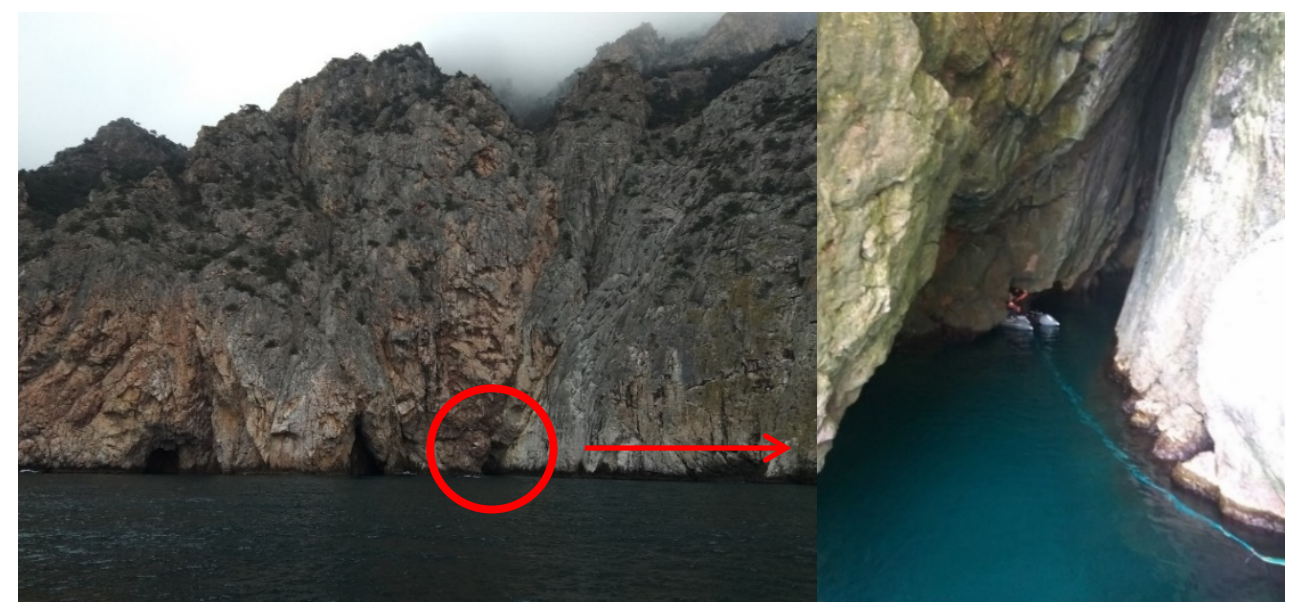

F i g. 1. Karst cavities near Cape Peleketo (left) and sampling in the karst cavity (right)

The submarine groundwater use as a source of fresh water has been known for over two thousand years and is described in The Geographica by Strabo ${ }^{4}$. Submarine waters of karst origin are developed in many countries for use as industrial and drinking water [3]. Similar work was carried out by Marine Tech Company in many countries ${ }^{5}$, including Malta, Sicily, Greece, the Gulf States, etc. The development and capture of submarine sources are economically viable in many regions.

The present paper aims to provide a comprehensive study of the submarine groundwater discharge at Cape Ayia using the hydrological, hydrochemical and radiochemical methods, and to determine the flux of submarine groundwater including the nutrients.

\section{Materials and Methods}

Sampling. The works were carried out during the coastal expedition to Cape Ayia on March 24, 2019, and on April 22-24, 2019, during the $106^{\text {th }} \mathrm{R} / \mathrm{V}$ Professor Vodyanitsky cruise (April 18 - May 13, 2019).

Works in the coastal expedition. Hydrological measurements were carried out at 20 stations in the karst cavity near Cape Peleketo and nearby. Samples were taken to determine the concentration of nutrients (silicic acid (Si), dissolved inorganic phosphorus (DIP), total dissolved phosphorus (TDP), ammonium, nitrites and nitrates), 6 samples with a volume of 200 liters were taken to determine the activity of ${ }^{226} \mathrm{Ra}$ and ${ }^{228} \mathrm{Ra}$ isotopes.

Surface samples were taken in $125 \mathrm{ml}$ plastic containers to determine the concentration of nutrients. The samples were filtered through membrane filters with a pore diameter of $0.45 \mu \mathrm{m}$ (Vladisart) and analyzed on the same day. Sampling

\footnotetext{
${ }^{4}$ Strabon, 1994. Geography. Moscow: Ladomir, 944 p. (in Russian).

${ }^{5}$ Marine Tech, expert in marine environment, USV and survey. 2020. [online] Available at: http://www.marinetech.fr/ [Accessed: 18 January 2021].
} 
to determine the activity of ${ }^{226} \mathrm{Ra}$ and ${ }^{228} \mathrm{Ra}$ was carried out by a vibration pump; the samples were immediately filtered through a polypropylene cartridge with a pore diameter of $1 \mu \mathrm{m}$ into $25 \mathrm{~L}$ plastic cans. Then the samples were transported to the onshore laboratory where the sorption concentration of ${ }^{226} \mathrm{Ra}$ and ${ }^{228} \mathrm{Ra}$ isotopes was carried out.

Works on R/V Professor Vodyanitsky. During the R/V Professor Vodyanitsky expedition, hydrological measurements were carried out at 7 stations, as well as sampling to determine the concentration of nutrients (Si, DIP, TDP and the sum of nitrites and nitrates) and the activity of ${ }^{226} \mathrm{Ra}$ and ${ }^{228} \mathrm{Ra}\left(1 \mathrm{~m}^{3}\right)$. The samples were filtered through membrane filters with a pore diameter of $0.45 \mu \mathrm{m}$ (Vladisart) and frozen for analysis in the onshore laboratory. Sampling to determine the activity of ${ }^{226} \mathrm{Ra}$ and ${ }^{228} \mathrm{Ra}$ was carried out with a submersible pump; the samples were immediately filtered through a polypropylene cartridge with a pore diameter of $1 \mu \mathrm{m}$. Then, the sorption of radium was made onboard.

Fresh water sampling. On September 29, 2019 water sampling was carried out to determine the concentration of nutrients at the Ayazma-Chokrak spring (44.47079 $\left.{ }^{\circ} \mathrm{N}, 33.64401^{\circ} \mathrm{E} ; 44.47082^{\circ} \mathrm{N}, 33.64393^{\circ} \mathrm{E}\right)$. On August 19, 2019 water sampling was carried out to determine the ${ }^{226} \mathrm{Ra}$ and ${ }^{228} \mathrm{Ra}$ activity (100 L) at the Despita spring on the way to the Baydarskiye Vorota pass $\left(44.42201^{\circ} \mathrm{N}, 33.78410^{\circ} \mathrm{E}\right)$.

Sorption of ${ }^{226} \mathrm{Ra}$ and ${ }^{228} \mathrm{Ra} .{ }^{226} \mathrm{Ra}$ and ${ }^{228} \mathrm{Ra}$ isotopes were extracted according to the procedure described in [19] using our own output fiber based on $\mathrm{MnO}_{2}$. When extracting from samples with a volume of $200 \mathrm{~L}$, two columns with a fiber mass of $5 \mathrm{~g}$ were used; from samples with a volume of $1 \mathrm{~m}^{3}$, two columns with a fiber mass of $20 \mathrm{~g}$ were used. The degree of ${ }^{226} \mathrm{Ra}$ and ${ }^{228} \mathrm{Ra}$ extraction was calculated according to the following formula [19]:

$$
S=\left(1-\frac{B}{A}\right) 100 \%,
$$

where $A$ and $B$ are the radionuclide activities on the first and second columns, respectively.

The degree of radium isotopes extraction was $90 \pm 6 \%$ [19].

Determination of the ${ }^{226} \mathrm{Ra}$ and ${ }^{228} \mathrm{Ra}$ activity. After concentration, the sorbent was squeezed out to remove excess seawater, dried in an oven at $80{ }^{\circ} \mathrm{C}$ and ashed at $700{ }^{\circ} \mathrm{C}$ for $8 \mathrm{~h}$. Then, the ash was placed in Petri dishes (55 mm in diameter) and poured with epoxy resin. The activity of radionuclides was measured on a lowbackground semiconductor $\gamma$-spectrometer with a detector made of high-purity germanium (GC3020) 3 weeks after resin embedding.

The ${ }^{226} \mathrm{Ra}$ activity was determined by the daughter radionuclide ${ }^{214} \mathrm{~Pb}$ with an energy of $351.9 \mathrm{keV},{ }^{228} \mathrm{Ra}$ - by the daughter ${ }^{228} \mathrm{Ac}$ with an energy of $911.6 \mathrm{keV}$ $\left(T_{1 / 2}=6.1\right.$ ч, q $\left.\gamma=27.7 \%\right)$. 
The values of ${ }^{226} \mathrm{Ra}$ and ${ }^{228} \mathrm{Ra}$ activity are provided below. The relative error in the determination of ${ }^{226} \mathrm{Ra}$ was $7-10 \%,{ }^{228} \mathrm{Ra}-13-16 \%$. The gamma spectrometer was calibrated using the certified sources.

Determination of the nutrient concentration. The main elements of the nutrient cycle were determined photocolorimetrically (RD No. 52.0.740-2010, RD No. 52.10.738-2010, RD No. 52.10.744-2010 and RD No. 52.10.745-2010) [20] mineral phosphorus - by molybdenum blue, silicon - by the silicon-molybdenum complex. Nitrates (reduced to nitrites) and nitrites were determined by the azo dye formed upon interaction with the Griss reagent on a two-channel AutoAnalyzer AA II flow autoanalyzer (Bran+Luebbe, Switzerland) [21]. Ammonium was also determined photocolorimetrically by indophenol blue. Water samples were taken into the specially prepared (washed with dilute hydrochloric acid and distilled water) polyethylene flasks, which were previously rinsed twice with the sample taken.

The obtained values of the nutrient concentration are also provided below. The relative determination error for the concentration of DIP and TDP $0.21 \mu \mathrm{M}$ was $2 \%$, for the concentration range $2-8 \mu \mathrm{M}-1.5 \%$; for the concentration of $\mathrm{NH}_{4}{ }^{+}$ions of $0.2 \mu \mathrm{M}-15 \%$, for $1 \mu \mathrm{M}-4 \%$. The relative error in the silicic acid determination for the concentration of $1.1 \mu \mathrm{M}-2 \%, 10.8 \mu \mathrm{M}-0.13 \%, 18.8-0.5 \%$, nitrates and nitrites for a concentration range of $0-1 \mu \mathrm{M}-0.1$ and $0.01 \%$ respectively.

Hydrological survey. Expeditionary research was performed by the probing biophysical complex Condor (RPE "Aquastandard", TS 431230-006-002419042015; (EAEU CN of FEA 902750000 0. EAEU Declaration of Conformity N RU D-RU.EM03.A.00096/19). Measurement errors are: temperature $\pm 0.05{ }^{\circ} \mathrm{C}$, salinity $\pm 0.01 \%$, current velocity $\pm 0.05 \mathrm{~m} / \mathrm{s}$, current direction $\pm 3^{\circ}$.

\section{Results and Discussion}

General description of the study area. Expeditionary work was carried out in the coastal area in a small bay near Cape Ayia formed by Cape Peleketo. According to a number of works $[13,15]$, the main submarine source is located in this area, in the Ekaterininskiy Grotto. The main challenge was to work under steep cliffs with a height of more than $100 \mathrm{~m}$ and to take seawater samples in a narrow karst cavity.

Hydrological survey. Based on the measurements performed in the surface layer and the vertical distribution, significant salinity gradients of $12-18.8 \%$ were determined in spring. It was also found that lighter brackish waters spread in a narrow layer of about $0.5 \mathrm{~m}$ thick (Fig. 2, $d$ ). This fact was taken into account when calculating the flux (discharge) of the submarine source.

${ }^{6}$ Sapozhnikov, V.V., Agatova, A.I., Arzhanova, N.V., Mordasova, N.V., Lapina, N.M., Zubarevich, V.L., Luk'janova, O.N. and Torgunova, N.I., 2003. Guidelines for the Chemical Analysis of Sea and Fresh Waters in Environmental Monitoring of Fishery Reservoirs and Promising World Ocean Areas. Moscow: VNIRO, 202 p. (in Russian). 


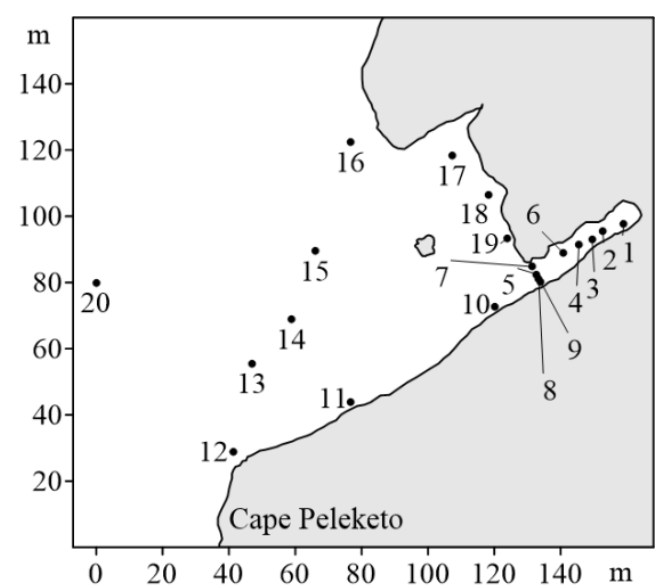

a
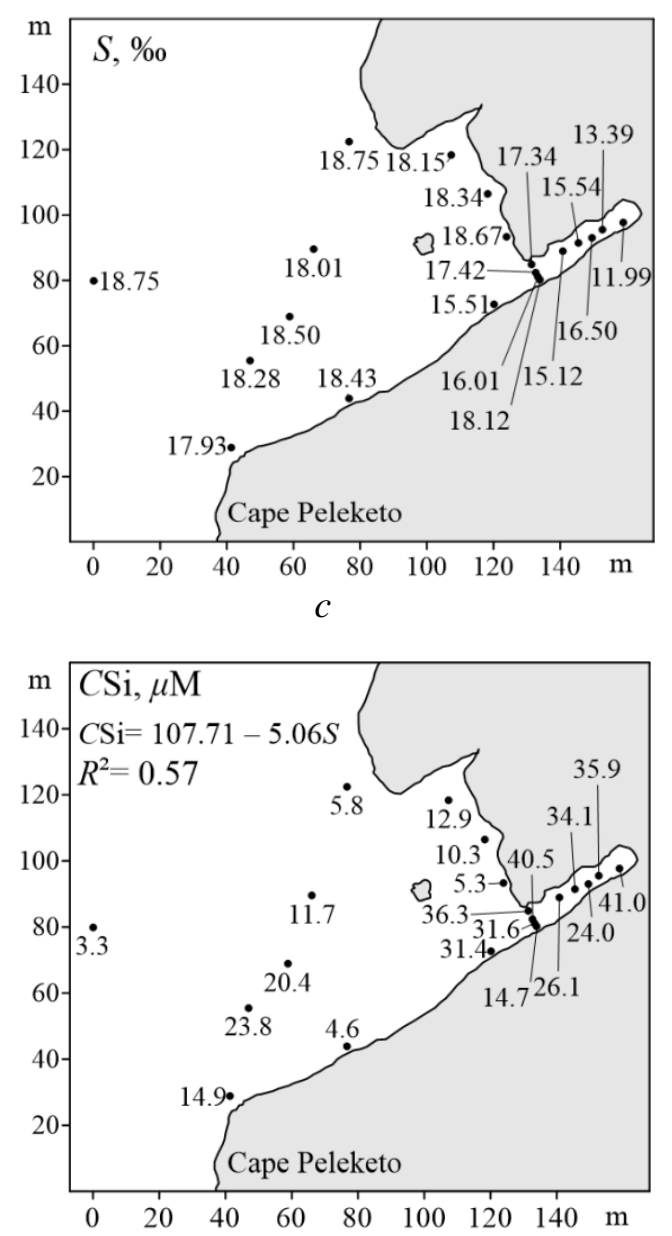

e

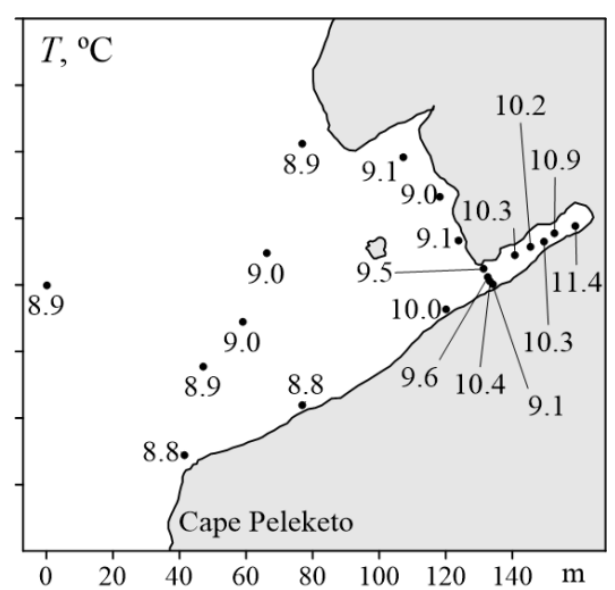

b

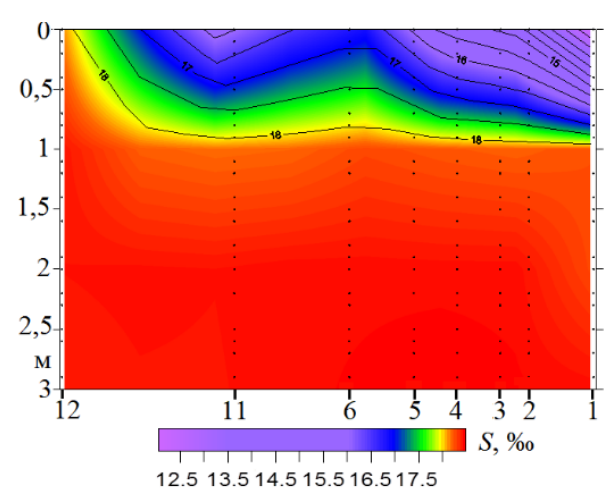

$d$

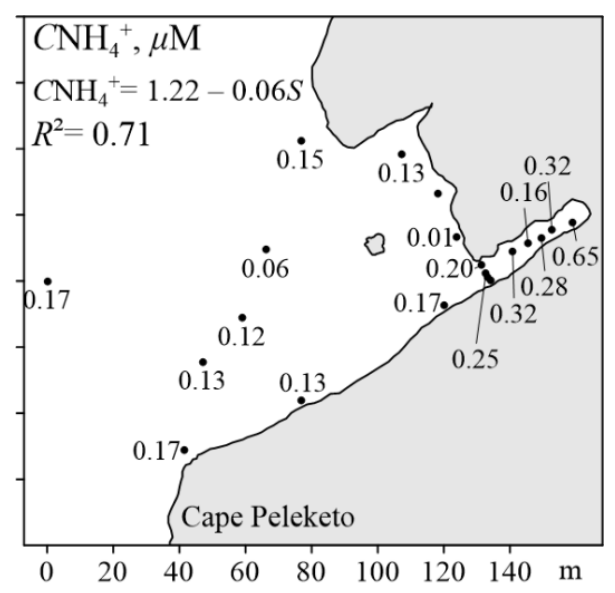

f 


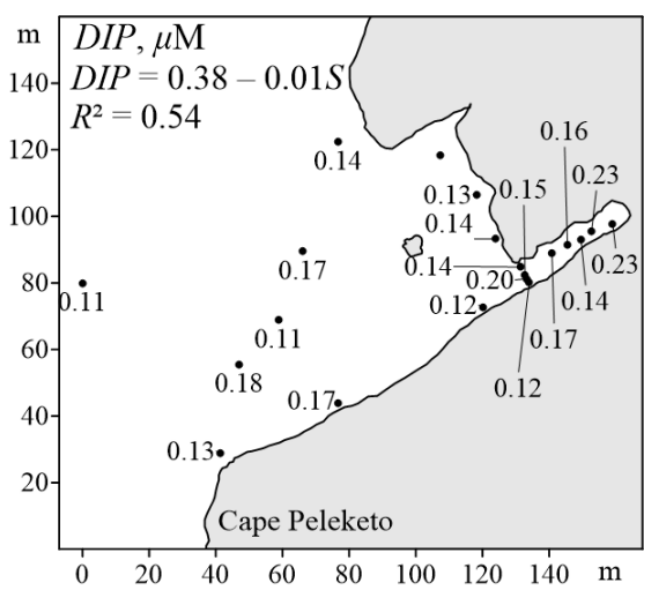

$g$

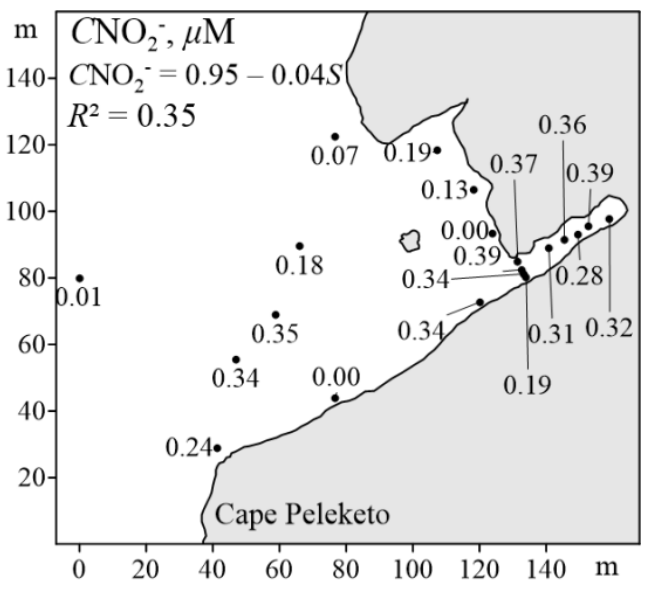

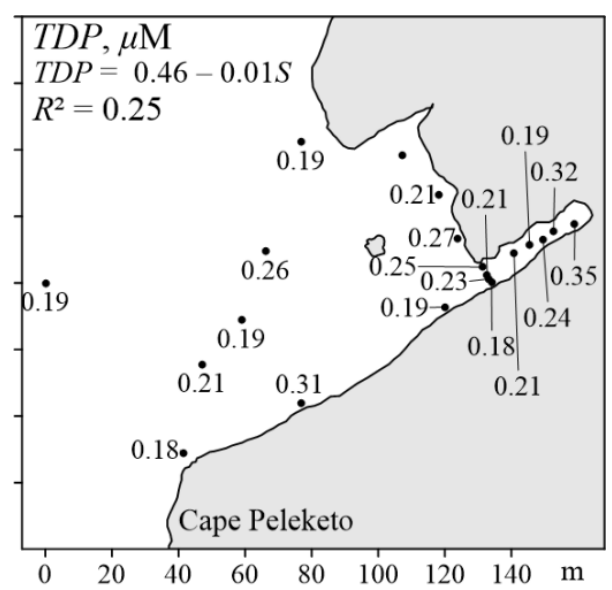

$h$

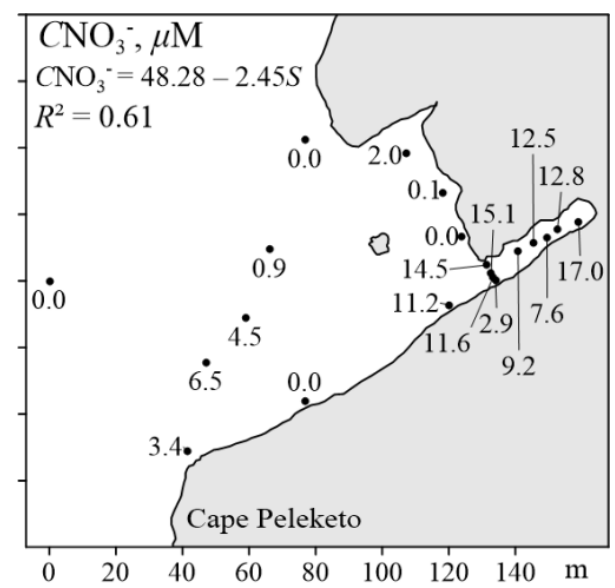

i

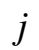

F i g. 2. Map of the stations (a) and distribution of temperature (b), salinity (c), salinity profiles at section 1-12 (d), silicic acid $(e)$, ammonium $(f)$, dissolved inorganic phosphorus $(g)$, total dissolved phosphorus $(h)$, nitrites $(i)$ and nitrates $(j)$

${ }^{226} \mathrm{Ra},{ }^{228} \mathrm{Ra}$ isotopes. Radiotracer methods have been used to search for the centers of submarine groundwater discharge for a long time [10]. The IAEA recommends them for studying this phenomenon in coastal areas [2]. Short-lived ${ }^{223} \mathrm{Ra},{ }^{224} \mathrm{Ra}$ and long-lived ${ }^{226} \mathrm{Ra},{ }^{228} \mathrm{Ra}$ of terrigenous origin have become most widespread for estimating the flow rate of submarine discharge. Fig. 3 shows the distribution of specific activity of ${ }^{226} \mathrm{Ra},{ }^{228} \mathrm{Ra}$ in the samples taken during the expeditions. 

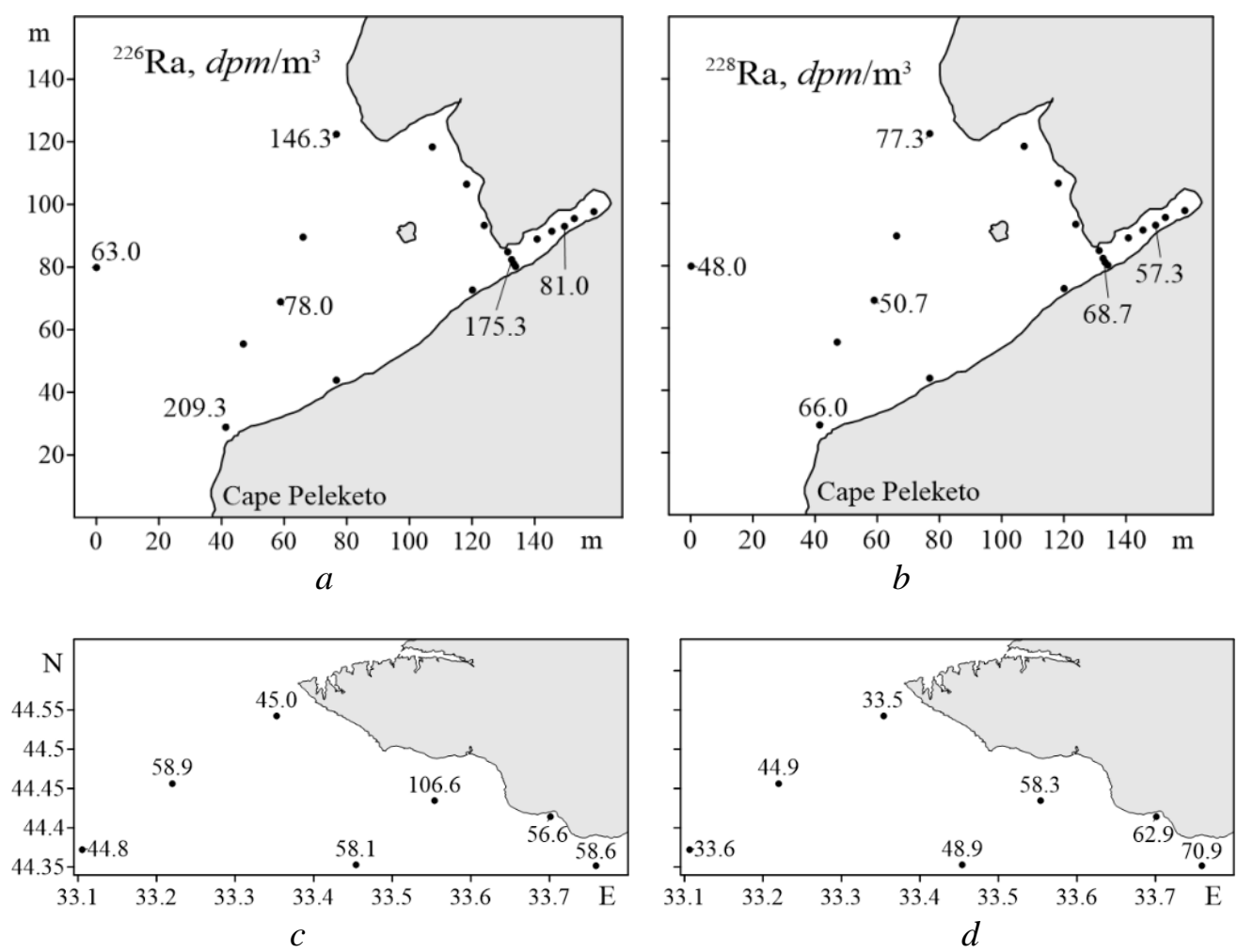

F i g. 3. Distribution of ${ }^{226} \mathrm{Ra}$ and ${ }^{228} \mathrm{Ra}$ activity at the stations in the Cape Ayia area $(a, b)$ and at the background stations $(c, d)$

The object under study is a karst cavity open to the sea on one side. Taking this feature into account, the researchers suggested using the mixing formula to determine the water output [13-15]:

$$
Q=\iint_{00}^{H L} U_{\mathrm{av}}(x, y) \frac{A_{\mathrm{b}}-A(x, y)}{A_{\mathrm{b}}-A_{\mathrm{n}}} d x d y,
$$

where $Q$ is the flow of submarine groundwater; $U_{\mathrm{av}}(x, y)$ is the average current velocity in a point of section $x, y$; $H, L$ are the maximum thickness $(0.5 \mathrm{~m})$ and width $(7 \mathrm{~m})$ of the surface layer of brackish water; $A_{\mathrm{b}}$ is the background activity of ${ }^{228} \mathrm{Ra}$ or ${ }^{226} \mathrm{Ra}$; $A(x, y)$ is the activity of ${ }^{228} \mathrm{Ra}$ or ${ }^{226} \mathrm{Ra}$ in a point of section $x, y ; A_{\mathrm{n}}$ is the mean activity of ${ }^{228} \mathrm{Ra}$ or ${ }^{226} \mathrm{Ra}$ in fresh water.

Using this formula, it was obtained that according to the activity of ${ }^{228} \mathrm{Ra}$ and ${ }^{226} \mathrm{Ra}$ (Tables 1, 2), the water output in the source in spring of 2019, was $0.092 \mathrm{~m}^{3} / \mathrm{s}\left(7960 \mathrm{~m}^{3} /\right.$ day $)$ and $0.087 \mathrm{~m}^{3} / \mathrm{s}\left(7534 \mathrm{~m}^{3} /\right.$ day $)$, respectively. These results were obtained using the data of the $106^{\text {th }} \mathrm{R} / \mathrm{V}$ Professor Vodyanitsky cruise when the average background activity values of ${ }^{228} \mathrm{Ra}$ and ${ }^{226} \mathrm{Ra}$ were $50 \pm 15$ and $61 \pm 21$ $\mathrm{dpm} / \mathrm{m}^{3}$ (disintegration per minute), respectively. Besides we used the activity of ${ }^{228} \mathrm{Ra}$ and ${ }^{226} \mathrm{Ra}$ at station 6 , according to the data of the spring expedition, that was 
68.7 and $175.3 \mathrm{dpm} / \mathrm{m}^{3}$ (Table 2) and the activity of radium isotopes in the fresh water of the Despita spring - 135 and $605 \mathrm{dpm} / \mathrm{m}^{3}$, which is slightly lower than the values given in [22]. The current velocity at the station was $11.9 \mathrm{~cm} / \mathrm{s}$.

Table 1

Distribution of the parameters in the surface layer at the background stations

\begin{tabular}{c|c|c|c|c|c}
\hline $\begin{array}{c}\text { Station } \\
\text { number }\end{array}$ & $D I P, \mu \mathrm{M}$ & $\mathrm{Si}, \mu \mathrm{M}$ & ${ }^{228} \mathrm{Ra}, d p m / \mathrm{m}^{3}$ & ${ }^{226} \mathrm{Ra}, d p m / \mathrm{m}^{3}$ & $\begin{array}{c}{ }^{228} \mathrm{Ra} / \\
{ }^{226} \mathrm{Ra}\end{array}$ \\
\hline 1 & 0.10 & 1.7 & 33.5 & 45.0 & 0.75 \\
3 & 0.08 & 2.9 & 44.9 & 58.9 & 0.76 \\
4 & 0.08 & 3.4 & 33.6 & 44.8 & 0.75 \\
5 & 0.14 & 2.0 & 48.9 & 58.1 & 0.84 \\
6 & 0.07 & 1.0 & 58.3 & 106.6 & 0.55 \\
7 & 0.09 & 1.8 & 62.9 & 56.6 & 1.11 \\
\hline
\end{tabular}

Station 6 located in the karst cavity alignment was chosen for calculating the water discharge due to the following reasons. According to [15] and our observations, in this karst cavity there are two groundwater outflows - at the apex and at the exit. This explains the presence of two zones of freshening and two zones with relatively high concentrations of nutrients in the cavity. At the stations 3 and 4 between these zones, salinity values are increased, and the concentration of nutrients and radium at station 3 is less than at station 6 .

The discharge data given in [15] (1915 $\mathrm{m}^{3} /$ day, using salinity and silicic acid concentration) were obtained in September 2007 after an abnormally hot and dry summer.

The obtained values of ${ }^{228} \mathrm{Ra},{ }^{226} \mathrm{Ra}$ activity correlate poorly with the salinity for the following reasons. The error in measuring ${ }^{228} \mathrm{Ra},{ }^{226} \mathrm{Ra}$ activity has the greatest value in comparison with other parameters. A total of 6 samples were taken, the salinity at the sampling stations did not cover the entire range that was observed in the study area. Also, 20 samples were taken to determine the content of nutrients. For all the measured parameters in the salinity range of 15-19\%o, a noticeable scatter of values was observed. For a number of elements the increased values were recorded at the stations distant from the karst cavity. This is explained by the presence of unknown discharge sources located at the bottom, as well as along the southwestern wall of Cape Ayia [15]. 


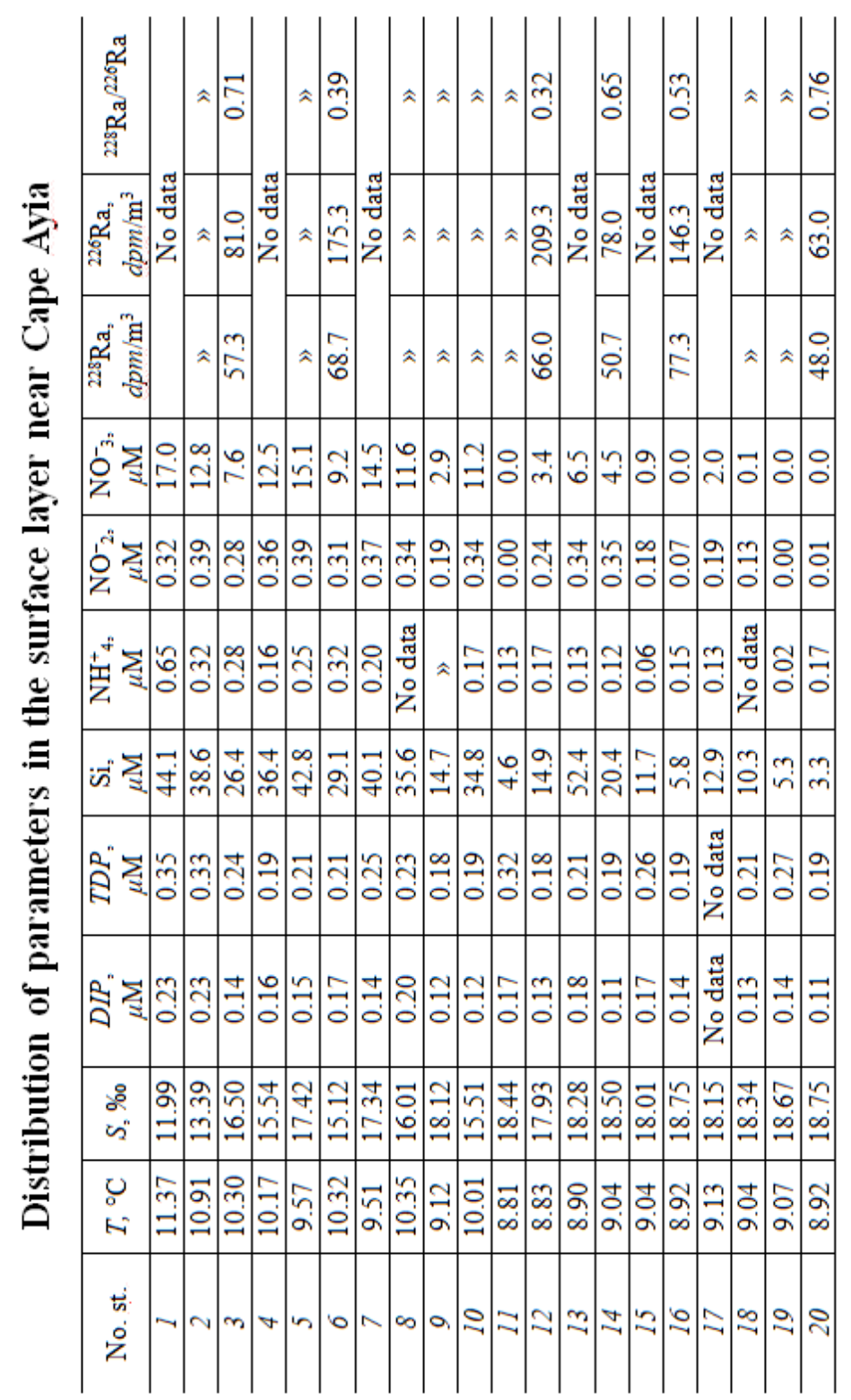


The analysis of ${ }^{228} \mathrm{Ra} /{ }^{226} \mathrm{Ra}$ ratio is of great interest. According to [22], ${ }^{228} \mathrm{Ra} /{ }^{226} \mathrm{Ra}$ value is higher in the seawater, since the concentration of ${ }^{228} \mathrm{Ra}$ in it is higher than that of ${ }^{226} \mathrm{Ra}$. In the fresh water, the situation is the opposite. Thus, ${ }^{228} \mathrm{Ra} /{ }^{226} \mathrm{Ra}$ ratio of 0.76 was obtained for the "seaward" samples, and 0.39 for the samples located close to the submarine source. Note that the salinity in the region studied in [22] was oceanic (33$36 \%$ o), which is higher than in our study area. Similarly, in this work relatively low ${ }^{228} \mathrm{Ra} /{ }^{226} \mathrm{Ra}$ values were observed at the following stations: at background station 5 located in front of the exit from the Balaklava Bay, which is caused by a significant discharge of fresh sewage waters (about 3 million $\mathrm{m}^{3}$ per year) [23]; at stations 6 and 12 near the karst cavity, which is explained by the large proportion of fresh water in the sample. Accordingly, the values of ${ }^{228} \mathrm{Ra} /{ }^{226} \mathrm{Ra}$ are higher in the samples with a larger seawater proportion.

Nutrients. In [13-15], the concentration of silicic acid was applied as a tracer of submarine discharge in the studied region, and in [15] the concentration of phosphate ions was also used for this purpose. The concentration of silicic acid correlated with salinity, the dependence equations are as follows:

$$
\begin{gathered}
C(\mathrm{Si})=-6.1 S+113.5(\text { September } 2007), \\
C(\mathrm{Si})=-6.76 S+124.3(\text { August } 1994), \\
C(\mathrm{Si})=-6.1 S+109.6(\text { autumn } 1993) .
\end{gathered}
$$

The obtained dependence is described by the following relation (Fig. 2,e):

$$
C(\mathrm{Si})=-5.1 S+107.71
$$

which is quite close to the previously published data.

According to [15], the dependence of dissolved inorganic phosphorus concentration on the salinity is as follows:

$$
C(D I P)=-0.019 S+0.349 \text { (September 2007). }
$$

The obtained dependence is described by the following relation (Fig. 2, g):

$$
C(D I P)=-0.01 S+0.38 \text {, }
$$

which also correlates well with the previously published data.

Similarly, the flows of submarine groundwater were calculated by the mixing formula using the salinity and concentration of nutrients. At the same time, the mean values at the 7 stations obtained during the cruise of R/V Professor Vodyanitsky were selected as the background DIP and silicic acid concentration. Since the samples taken during this expedition were frozen and measured after the expedition, there is no data on ammonium, nitrites and nitrates. The background values of these elements for estimating the flows were taken from the data at station 20 of the coastal expedition. Approximation of the values of the nutrient concentration to zero salinity gives the estimated concentrations of nutrients in groundwater. For radium isotopes, the values obtained for spring water were taken (Table 3). The daily water discharge rate in the submarine water source calculated using ammonium, TDP and nitrite ions differs significantly from the rest. At the same time, for TDP and nitrite ions, reliability values of the dependence of these hydrochemical parameters on salinity are low. If they are excluded from the considered results as unreliable, then the average flow of submarine groundwater is about $8220 \pm 1200 \mathrm{~m}^{3} /$ day. 


\section{Data for estimating the fresh water flow from the karst cavity and its daily discharge}

\begin{tabular}{c|c|c|c|c|c}
\hline Parameter & $\begin{array}{c}\text { Value } \\
\text { at st. 6 }\end{array}$ & $\begin{array}{c}\text { Background } \\
\text { value }\end{array}$ & Groundwater & Flow, $\mathrm{m}^{3} / \mathrm{s}$ & $\begin{array}{c}\text { Daily discharge, } \\
\mathrm{m}^{3} / \mathrm{day}\end{array}$ \\
\hline $\mathrm{S}$ & 15.120 & 18.750 & 0.70 & 0.084 & 7235 \\
$\mathrm{C}(\mathrm{Si})$ & 29.100 & 2.000 & $104.20^{*}$ & 0.110 & 9542 \\
$\mathrm{DIP}$ & 0.170 & 0.090 & $0.38^{*}$ & 0.115 & 9927 \\
$\mathrm{TDP}$ & 0.210 & 0.190 & $0.45^{*}$ & 0.032 & 2768 \\
$\mathrm{NH}_{4}^{+}$ & 0.320 & 0.170 & $1.17^{*}$ & 0.062 & 5386 \\
$\mathrm{NO}^{-}$ & 0.310 & 0.010 & $0.92^{*}$ & 0.137 & 11863 \\
$\mathrm{NO}^{-}$ & 9.200 & 0.00 & $46.57^{*}$ & 0.082 & 7109 \\
${ }^{226} \mathrm{Ra}$ & 175.300 & 61.000 & 605.00 & 0.087 & 7534 \\
${ }^{228} \mathrm{Ra}$ & 68.700 & 50.000 & 135.00 & 0.092 & 7960 \\
\hline
\end{tabular}

* Calculated for salinity value $0.7 \%$.

Table. 4 shows the values of nutrient concentration calculated for underground water. For comparison, it also shows the values of nutrient concentration in the Ayazma-Chokrak spring. This spring is the closest to Cape Ayia and the centers of submarine discharge. The values of the nutrient concentration and the average value of the submarine groundwater flow make it possible to evaluate the nutrient flow as:

$$
F=Q C,
$$

where $F$ is the flow of the element, g/day; $Q$ is the mean value of the flow of submarine underground water, $1 /$ day; $C$ is the element concentration, $\mathrm{g} / \mathrm{l}$.

The nutrient flows in the spring of 2019 were calculated (Table 4) by the formula (3). It was revealed that more than $5 \mathrm{~kg}$ of nitrate nitrogen are removed from the karst cavity per day.

Table 4

Nutrient flows within the submarine groundwater

\begin{tabular}{l|c|c|c|c|c|c}
\hline \multirow{2}{*}{ Spring } & \multicolumn{6}{|c}{ Concentration, $\mu \mathrm{M}$} \\
\cline { 2 - 7 } & $\mathrm{Si}$ & $\mathrm{P}(D I P)$ & $\mathrm{P}(T D P)$ & $\mathrm{N}\left(\mathrm{NH}_{4}^{+}\right)$ & $\mathrm{N}\left(\mathrm{NO}_{2}^{-}\right)$ & $\mathrm{N}\left(\mathrm{NO}_{3}^{-}\right)$ \\
\hline Aiyaz'ma-Chokrak spring & 142.8 & 0.06 & 0.06 & 1.25 & 0.18 & 6.34 \\
\cline { 1 - 7 } Underground water & 104.2 & 0.38 & 0.45 & 1.17 & 0.92 & 46.57 \\
\cline { 1 - 6 } Fluxes, g/day & 23983 & 97 & 115 & 135 & 106 & 5359 \\
\hline
\end{tabular}

${ }^{*}$ Calculated for salinity value $0.7 \%$.

\section{Conclusions}

As a result of field studies, the distribution of hydrophysical, hydrochemical and radiochemical parameters in the water area adjacent to the known centers of PHYSICAL OCEANOGRAPHY VOL. 28 ISS. 1 (2021) 
submarine groundwater discharge was studied. The distribution of ${ }^{226} \mathrm{Ra},{ }^{228} \mathrm{Ra}$ isotopes, as well as some nutrients (ammonium, nitrite and nitrate ions) was studied for the first time. A significant (5-10 times) difference in the background and coastal concentrations of ${ }^{228} \mathrm{Ra},{ }^{226} \mathrm{Ra}$ and nutrients was revealed.

The submarine groundwater flows near Cape Ayia were determined using the data on salinity, ${ }^{226} \mathrm{Ra},{ }^{228} \mathrm{Ra}$ activity and nutrient concentration. The flow from the main center of submarine discharge is estimated at $8220 \pm 1200 \mathrm{~m}^{3} /$ day. The flows of nutrients with the submarine groundwater were also calculated.

The use of radiotracer methods for studying the discharge of individual known submarine discharge centers gives the results of the same order as the use of hydrological and hydrochemical methods. At the same time, the use of radiotracer methods makes it possible to estimate the total flows of submarine discharge on large (tens of kilometers) coastal scales, which allows us to take into account the entire volume from both known and unknown (fracture-vein sources, under-channel runoff, etc.) karst centers.

\section{REFERENCES}

1. IOC, 2004. Submarine Groundwater Discharge: Management Implications, Measurements and Effects. 35 p. Available at: https://wedocs.unep.org/handle/20.500.11822/854?show=full [Accessed: 18 January 2021].

2. IAEA, 2008. Nuclear and Isotopic Techniques for the Characterization of Submarine Groundwater Discharge in Coastal Zones. Results of a coordinated research project 20012006. IAEA-TECDOC-1595. Vienna: IAEA, 192 p. Available at: https://www.iaea.org/publications/7925/nuclear-and-isotopic-techniques-for-thecharacterization-of-submarine-groundwater-discharge-in-coastal-zones [Accessed: 18 January 2021].

3. Fleury, P., 2005. Sources Sous-Marines et Aquiferes Karstiques Côtiers Mediterraneens. Fonctionnement et Caracterisation. Paris: Université Pierre et Marie Curie, 286 p. Available at: https://tel.archives-ouvertes.fr/tel-00789234/document [Accessed: 18 January 2021].

4. Rodellas i Vila, V., 2014. Evaluating Submarine Groundwater Discharge to the Mediterranean Sea by Using Radium Isotopes. Barcelona: Universitat Autònoma de Barcelona, 190 p. Available at: https://www.tdx.cat/bitstream/handle/10803/285061/vrv1de1.pdf;jsessionid=528EC090F3C974CA E6F0FD4018EE5784?sequence=1[_Accessed: 18 January 2021].

5. Zektser, I.S., 2001. Groundwater as a Component of the Environment. Moscow: Scientific world, 328 p. Available at: https://www.rfbr.ru/rffi/ru/books/o_27088 [Accessed: 18 January 2021].

6. Zektser, I.S. and Dzhamalov, R.G., 2007. Submarine Groundwater. New York: CRC Press, $474 \mathrm{p}$.

7. $\quad$ Schubert, M., Knöller, K., Stollberg, R., Mallast, U., Ruzsa, G. and Melikadze, G., 2017. Evidence for Submarine Groundwater Discharge into the Black Sea - Investigation of Two Dissimilar Geographical Settings. Water, 9(7), 468. doi:10.3390/w9070468

8. Klimchouk, A., 2012. Krubera (Voronja) Cave. In: W. B. White and D. C. Culver, Eds., 2012. Encyclopedia of Caves. ${ }^{\text {nd }}$ Ed. New York: Academia Press, pp. 443-450. doi:10.1016/B978-012-383832-2.00063-3

9. Lyalko, V.I. and Shnyukov, E.F., 1980. On the Submarine Unloading of Groundwater on the Shelf of the Ukrainian Black Sea. Geological Journal, 40 (3), pp. 48-53. Available at: http://www.pseudology.org/science/lyalko_shnyukov1980.pdf [Accessed 18 January 2021] (in Russian).

10. Kiryakov, P.A.; Lisichenko, G.V.; Emelyanov, V.A. and Mitropolsky, A.Yu., 1982. On the Identification of Foci of Submarine Discharge of Groundwater Using Radon Photography. Water Resources, (5), pp. 153-157 (in Russian). 
11. Shnyukov, E.F., Kleschenko, S.A., Mitin, L.I., Kleschenko, L.G. and Markov, A.A., 1989. [Searches for Submarine Sources in Canyons of the Continental Margin of the Southern Coast of Crimea]. Preprint. Kiev: Institute of geological sciences Academy of sciences USSR, 39 p. (in Russian).

12. Yurovsky, Yu.G., 2013. [Underground Waters Offshore. Tasks and Methods of Study]. Palmarium Academic Publishing, 336 p. (in Russian).

13. Kondrat'ev, S.I., Shchetinin, Yu.T., Dolotov, N.N. and Androsovich, A.I., 1998. Hydrological and Chemical Characteristics of the Submarine Freshwater Source near Cape Aiya. Physical Oceanography, 9(3), pp. 217-224. doi:10.1007/BF02523232

14. Kondratev, S.I., Dolotov, V.V., Moiseev, Y.G. and Shchetinin, Yu.T., 2000. Submarine Springs of Fresh Water in the Region from Cape Feolent to Cape Sarych. Physical Oceanography, 10(3), pp. 257-272. doi:10.1007/BF02509223

15. Kondrat'ev, S.I., Prusov, A.V. and Yurovskii, Y.G., 2010. Observations of the Submarine Discharge of Underground Waters (South Coast of the Crimea). Physical Oceanography, 20(1), pp. 28-41. https://doi.org/10.1007/s11110-010-9065-3

16. Mejías, M., Ballesteros, B.J., Antón-Pacheco, C., Domínguez, J.A., Garcia-Orellana, J., Garcia-Solsona, E. and Masqué, P., 2012. Methodological Study of Submarine Groundwater Discharge from a Karstic Aquifer in the Western Mediterranean Sea. Journal of Hydrology, 464-465, pp. 27-40. https://doi.org/10.1016/j.jhydrol.2012.06.020

17. Yurovsky, Yu.G., 2000. Evaluation of the Submarine Discharge of Karst Waters in the Region of Cape Aiya. Physical Oceanography, 10(3), pp. 283-286. doi:10.1007/BF02509225

18. Kayukova, E.P. and Yurovsky, Yu.G., 2017. Water Resources of the Crimea. Water Resources, 44(7), pp. 886-891. https://doi.org/10.1134/S0097807817070053

19. Dovhyi, I.I., Kremenchutskii, D.A., Bezhin, N.A., Shibetskaya, Yu.G., Tovarchii, Ya.Yu., Egorin, A.M., Tokar, E.A. and Tananaev, I.G., 2020. $\mathrm{MnO}_{2}$ Fiber as a Sorbent for Radionuclides in Oceanographic Investigations. Journal of Radioanalytical and Nuclear Chemistry, 323(1), pp. 539-547. doi:10.1007/s10967-019-06940-9

20. Grasshoff, K., Kremlingl, K. and Ehrhardt, M., 1999. Methods of Seawater Analysis. Weinheim: WILEY-VCH Verlag, 600 p. https://doi.org/10.1002/9783527613984

21. Wurl, O., ed., 2009. Practical Guidelines for the Analysis of Seawater. Boca Raton: CRC Press, 408 p. https://doi.org/10.1201/9781420073072

22. Moore, W.S., 2003. Sources and Fluxes of Submarine Groundwater Discharge Delineated by $\begin{array}{llll}\text { Radium } \quad \text { Isotopes. } & \text { Biogeochemistry, }\end{array}$ doi:10.1023/B:BIOG.0000006065.77764.a0

23. Gurov, K.I., Ovsyany, E.I., Kotelyanets, E.A. and Konovalov, S.K., 2015. Factors of Formation and Features of Physical and Chemical Characteristics of the Bottom Sediments in the Balaklava Bay (the Black Sea). Physical Oceanography, (4), pp. 46-52. doi:10.22449/1573160X-2015-4-46-52

About the authors:

Illarion I. Dovhiy, Senior Research Associate, Marine Hydrophysical Institute of RAS (2 Kapitanskaya str., Sevastopol, 299011, Russian Federation), Ph. D. (Chem.), ORCID ID: 00000001-8706-3810, dovhyi.illarion@yandex.ru

Nikolay A. Bezhin, Senior Research Associate, Marine Hydrophysical Institute of RAS (2 Kapitanskaya str., Sevastopol, 299011, Russian Federation), FSAEI HE SevSU (33 Universitetskaya str., Sevastopol, 299053, Russian Federation), Assistant Professor, Ph. D. (Tech.), ORCID ID: 00000002-1670-4251, nickbezhin@yandex.ru

Dmitry A. Kremenchutskii, Research Associate, Marine Hydrophysical Institute of RAS (2 Kapitanskaya str., Sevastopol, 299011, Russian Federation), ORCID ID: 0000-0002-8747-6612, d.kremenchutsky@gmail.com 
Ol'ga N. Kozlovskaya, Junior Research Associate, Marine Hydrophysical Institute of RAS (2 Kapitanskaya str., Sevastopol, 299011, Russian Federation), SPIN-code: 5386-4791, o.n.kozlovska@gmail.com

Aleksey I. Chepyzhenko, Senior Research Associate, Marine Hydrophysical Institute of RAS (2 Kapitanskaya str., Sevastopol, 299011, Russian Federation), SPIN-code: 3599-9653, ecodevice@yandex.ru

Anna V. Verterich, Student, D. Mendeleev University of Chemical Technology of Russia, (9 Miusskaya sq., Moscow, 125047, Russian Federation), anna.verterich2003@gmail.com

Yana Yu. Tovarchiy, Student, FSAEI HE SevSU (33 Universitetskaya str., Sevastopol, 299053, Russian Federation), SPIN-code: 9497-5220, yanapapina1998@gmail.com

Yulia G. Shibetskaya, Student, FSAEI HE SevSU (33 Universitetskaya str., Sevastopol, 299053, Russian Federation), engineer, Marine Hydrophysical Institute of RAS (2 Kapitanskaya str., Sevastopol, 299011, Russian Federation), SPIN-code: 7765-8638, garaldaaa@gmail.com

Danil Yu. Chaikin, Student, D. Mendeleev University of Chemical Technology of Russia, (9 Miusskaya sq., Moscow, 125047, Russian Federation), SPIN-code: 3806-5655, chajkin.danil.02@inbox.ru

Contribution of the co-authors:

Illarion I. Dovhiy - participation in expeditionary work; sampling; processing of samples for radium isotopes; discussion and analysis of the obtained results

Nikolay A. Bezhin - participation in expeditionary work; sampling; discussion and analysis of the obtained results

Dmitry A. Kremenchutskii - participation in expeditionary work; sampling; determination of the concentration of radium isotopes; discussion and analysis of the obtained results

Ol'ga N. Kozlovskaya - measurement of nutrient concentration; processing of the obtained data; discussion and analysis of the obtained results

Aleksey I. Chepyzhenko - participation in expeditionary work (hydrological survey); discussion and analysis of the results

Anna V. Verterich - nutrient concentration measurement

Yana Yu. Tovarchiy - sorbent preparation

Yulia G. Shibetskaya - participation in expeditionary research; sampling

Danil Yu. Chaikin - measurement of nutrient concentration

All the authors have read and approved the final manuscript.

The authors declare that they have no conflict of interest. 